\title{
Challenges in implementing CLT at secondary schools in rural Bangladesh
}

\author{
Md. Morshedul Alam \\ Department of English Language \& Literature, \\ International Islamic University Chittagong, Bangladesh
}

\begin{abstract}
This paper tries to identify the factors that hinder implementing Communicative Language Teaching (CLT) in the secondary schools in rural Bangladesh. This article takes a qualitative approach, and it is carried out in four rural schools in Banskhali, which is situated in Chittagong district in Bangladesh. Eight secondary level English language teachers were interviewed to generate data about the problems in implementing CLT in their respective institutions. The findings indicate several challenges that include: shortage of skilled teachers, unusually large class size, deficiency of modern materials used in CLT oriented classrooms, etc. This research may provide implications for the language policy makers and the practitioners for the improvement of CLT practices in the rural contexts of Bangladesh.
\end{abstract}

Keywords Communicative Language Teaching (CLT), Grammar Translation Method (GTM), CLT implementation, Secondary level, Rural schools in Bangladesh

Paper type Research paper

\section{Introduction}

In English language teaching, Communicative Language Teaching (CLT) came into being while Grammar Translation Method (GTM) failed to fulfill the needs and expectations of the policy makers around the world. During 1970s, some ELT practitioners and educators in Europe and North-America initiated CLT with the aim of promoting students' communicative skills (Savignon, 1987). Due to the impact of globalization and the necessity for higher education in many overseas countries, where English is spoken as a second language, have adopted CLT to teach English to the secondary level students (Zhu, 2003; Yoon, 2004). CLT was introduced in Bangladesh during the 1990s. In Bangladesh, CLT was introduced through a BangladeshUK jointly funded project named: English Language Teaching Improvement Project (ELTIP). Eventually,

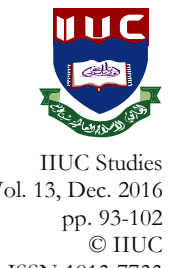

ISSN 1813-7733 


\section{IIUC STUDIES, 13}

CLT oriented textbooks were produced by the National Curriculum and Textbook Board (NCTB), a department of Education Ministry(MoE), of Bangladesh for the implementation of CLT in all secondary and higher secondary level schools, colleges, and madrasahs (religious institution) with an aim to improve learners' communicative competence.

Communication is the principal target of teaching and learning a language through CLT. It includes the integration of different skills of language (Richards \& Rodgers, 2001). Nevertheless, a communicative competence based curriculum strengthens not only teaching grammatically error free statements, but also improving the power of using language in the authentic and real-world environment (Nunan, 1988). The main feature of CLT is that it wants to ensure students' application of language learning in practical situations. Consequently, CLT most often gives priority to practical skill of communication over theoretical knowledge of language. Chowdhury (2003) focuses on the matters relating to the match and mismatch of communicative language teaching of the students not only of Bangladesh but also of other countries of Asia where EFL situations prevail. He describes the cultural significance and how it influences teachers in language teaching and learning. He opines that materials of teaching language should be reformed and redesigned in a new framework with the acknowledgement of the reality of the Bangladesh context.

Hamid and Baldauf (2008) present the notion that in Bangladesh when a new policy of language teaching named CLT was introduced after 1996, demanding the effectuation of communicative method, it was expected that CLT would function as a catalyst to improve the students' poor skill of communication and thus enhance the standard of English particularly the picture of English education in Bangladesh. But they think that the learning of the English language largely depends on a student's domestic, socio-economic and cultural factors. In that case, there is a big gap between urban and rural area students. In addition, they show that the emergence of private institutions in the field of education has added a new dimension on learning and teaching English in Bangladesh, where parents' of wealthy families afford private but standard institutions for their children. Hamid and Baldauf (2008) say that the existing CLT based curriculum of English is inappropriate in Bangladesh context where rural institutions are still lagging behind because of less qualified and untrained teachers, poor resources and allocations of facilities in comparison to urban schools where almost all modern facilities are available.

Despite spending a lot of time and money to implement and improve CLT within Bangladesh, the outcome has not been as per expectation (Ali \& Walker, 2014). Hamid and Baldauf (2008) portray the negligible condition of CLT reality in rural Bangladesh. Hamid and Baldauf (2008) 
and Ali and Walker (2014), provide critical insights into some of the complex causes behind the poor ELT reality in Bangladesh. The present research also aims to explore the challenges that appear in implementing CLT in rural Bangladesh. It will contribute further to understanding the problems in implementing CLT particularly in rural Bangladeshi contexts. Many researchers have researches on the issues related to CLT; very few articles are about CLT in the south Asian context, in particular Bangladesh. Although much of the literature is based on East Asia, such as China, South Korea, Japan, and Vietnam, a few articles on CLT in Bangladeshi context have also focused on the problems of CLT practice in rural Bangladesh. The purposes of this paper are to address the reasons that hinder implementing of Communicative Language Teaching (CLT) in the secondary schools in rural Bangladesh. The study focuses on the rural areas of Bangladesh which are still lagging behind in overall development. It also aims at adding the findings on the CLT practice especially in rural Bangladesh by exploring the problems that create obstacles to successful implementation of CLT in rural Bangladesh.

\section{Literature Review}

\subsection{Communicative Language Teaching (CLT)}

CLT, a language teaching method, started to develop during 1970s with Dell Hymes' (1972) publication. Hymes posits that linguistic efficiency alone is not adequate for students to be able to communicate within meaningful communicative contexts. He claims that language is not used discretely rather it is a means of social communication which takes place within society. He, therefore, claims for communicative competence which focuses both on learners' linguistic knowledge and their communication skills (Richards \& Schmidt, 2010). Hence, CLT takes on this approach and aims at developing learners' communicative competence so that they can use language within meaningful communicative contexts (Larsen-Freeman \& Anderson, 2011; Larseen-Freeman, 2000).

Brown (1994:81) suggests that communication be likely to take place in the classroom when (1) an abundant amount of practices in the class such as pair and group activities is carried; (2) practices are authentic and real life centered: (3) learners are motivated to generate language for realistic, fruitful interaction; and (4) activities are to drive learners for practical use of language even outside the classroom. Larsen-Freeman (2000: 65) also proposes that "it is important to facilitate small group and paired activities in which students have opportunities to communicate. The activities themselves often engage students in communicative task; such as filling information gaps, using genuine materials". Hymes (1972) opines that to know a language means knowing a set of grammatical, lexical, and phonological rules. Savignon (1991, 2002) discussed several 


\section{IIUC STUDIES, 13}

applications of CLT and focused that "Learners communicative needs provide a framework for elaborating program goals in terms of functional competence" (1991:266).

\subsection{Teachers' role in CLT}

The basic principle of CLT approach is that teachers should play role as facilitators to generate learner-centered classrooms and engage students in substantive and fruitful communications to enhance understandable language input for students and hope them to generate much input (Brown, 2007; Larsen-Freeman, 2000). Therefore, teachers are expected to design more ideas and learning materials with definite goals and think what materials for learning are to facilitate learners' learning of the language in EFL context (Brown, 2007; Celee-Muria, 2001).

In a communicative classroom, the roles of the teachers' and learners' Larsen-Freeman (1986:131) says "The teachers facilitate communication in the classroom". In this context, their principal concern is to create circumstances favourable to develop confidence among students of communication. In class room performance they should work as mentor by giving answers to student's questions and conducting their activities. Teachers must notice the mistakes and errors of the students so that they can work on more accuracy-based activities at a later time. In CLT class in EFL context, teachers should play role as a coordinator keeping engaged in the activities related to communicative competence together with students. Above all, students should be the real communicators in language class. They are used to playing active role in trying to make them understand and in comprehending others even though they possess incomplete knowledge of the target language. When teacher's role is less dominant than learners in a language class, learners are found as more sincere and enthusiastic accomplishers of their learning.

Remarking on the characteristics of student-student interaction and the teacher-student interaction, Larsen-Freeman (1986:133) says: "The teacher may present some part of the lesson, such as when working with linguistic accuracy. At other times, he is the facilitator of the activities, but he does not always himself interact with the students. Sometimes he is a co-communicator, but more often he establishes situations that prompt communication between and among the students. Students interact a great deal with one another. They do this in various configurations: pairs, triads, small groups, and whole group."

\subsection{Problems in implementing CLT}

The application of CLT to teaching English in Bangladesh context has recently been discussed broadly $(\mathrm{Li}, 1998)$. As the CLT method tries to comprise students' in more substantive and interactive learning tasks that contribute both to apprehensible input and learners' language input, the English language teachers in 
Bangladesh still consider it challenging and troublesome to apply the method and maximize learning proficiency, especially in EFL classroom (Ali \& Walker, 2014; Hamid \& Baldauf, 2008; Li, 1988).

CLT implementation in EFL context finds many challenges which according to Chang (2011) include: (a) lack of teacher-training (b) local culture of learning and teaching (c) language test and (d) lack of teachers' access to policy making process. In the context of Bangladesh, Ali and Walker (2014) have identified four broad reasons that encumber the implementation of CLT in the country. These barriers are (a) lack of adequate teachers' training (b) inconsistency in ELT practices (c) lack of cooperation among different stakeholders and (d) little impact of development projects. They suggest incorporating an ELT policy within the national ELT curriculum. According to Ali and Walker (2014:37) the ELT policy should comprise the following essential disclosures:

a. the public benefits of the country (i.e. how English can facilitate the socio-cultural benefit of Bangladesh);

b. the socio-linguistic and psycholinguistic needs of the learners;

c. systematical factors, i.e. the practicability of applying a language teaching guideline all over the country. The ELT experts opine that the methodology produced in the BANA (Britain, Australia and North America) countries should be contextualized as per the needs of the learners and teachers of a local context;

d. fruitful implementation of ELT in the classroom depends on the issues of ongoing teacher training, follow up training and addressing teachers' needs and wants;

e. evaluation of the outcome (i.e. what should be the method to evaluate the learners' outcome? what should be the rating scale? and what should be the criteria to evaluate the program?)

f. innovation, i.e. how is the overall ELT program going to be improved?

\section{Methodology}

\subsection{Aims}

This paper tries to address principal causes that hinder implementing CLT in rural Bangladesh. In doing so, the data are collected from four rural schools in Banskhali, which is situated in Chittagong district in Bangladesh. Eight English teachers from these schools were surveyed and interviewed. The research question of this paper is:

What are the challenges in implementing CLT in rural Bangladesh?

\subsection{Method}

This is a qualitative study in nature. The schools and the teachers were randomly selected. In this study, interviews and questionnaires were used as 


\section{IIUC STUDIES, 13}

instruments. Data were raised through face to face interview and a written questionnaire. The data generated insights that are related to the problems that the respondents face in applying CLT. The questionnaire was provided to write possible solutions to problem of implementation of CLT in rural secondary schools. The selected schools were physically visited by the researcher to interview and survey the respondents. In analysing and presenting the interview data, the teachers are coded as T1, T2 ...T8.

\section{Research Findings}

The data analyses show that English teachers find many problems in implementing CLT in rural context. The data are analyzed to examine the potential themes that relate to the research questions. The important themes are presented through a table (see, table 1 below). In keeping relation to the research question the findings are discussed later.

\begin{tabular}{cl}
\hline The Participants (Interviewees) & \multicolumn{1}{c}{ Themes } \\
\hline T5 & Depending on coaching center and house tutors \\
T8 & Lack of supervision \\
T2 & Lack of trained teachers \\
T1 & Unusually large Class size \\
T3 & Insufficient teaching aids \\
T4 & Teachers are overburdened \\
T5 & Weak background in English \\
T4 & GPA oriented mentality of students \\
T6 & Anglo phobia \\
T7 & Introvert attitude \\
T6 & Poor socio-economic condition \\
T8 & Wrong selection of training \\
T7 & Lack of motivation \\
T2 & Lack of confidence \\
T1 & Corrupt administration \\
T3 & Lack of follow up training \\
\hline
\end{tabular}

\section{Table 1: Data Themes}

Majority of the English language teachers of the rural secondary level schools in Chittagong, Bangladesh have pointed out many hurdles to implementing CLT in rural areas. As observed from the analysis of the data, T1 states that one of the main barriers of implementing the method is the unusually large class size. T8 also supports the statement of T1 and he added that lack of supervision from authority is also hindering the CLT approach in rural secondary level schools.

Lack of training seems to be another problem that creates hurdles to the CLT implementation in rural Bangladesh. T2 and T5 opine that lack of trained teachers is another impediment to implementing CLT in rural areas. It also appears to $\mathrm{T} 5$ that students prefer exam-oriented English teaching 
and therefore they prefer to go to private classes and coaching centers instead of the classes in schools. T2 also supports the statement of T5.

To T3, the main difficulty in implementing CLT in rural areas is insufficient teaching aids. Many rural secondary schools are deprived of audio-visual class room, projector and 24 hour electricity supply, etc. T4 also addresses the same problem. On the other hand, T4 opines that GPA oriented mentality of the learners is also an alarming obstacle to implementing the method in rural Bangladesh. Students' sole target is not to acquire knowledge but to get good GPA. Besides T4 and T3, another English teacher also subscribes to the same opinion.

Teaching load is another problem that creates obstacle to implementing CLT in rural Bangladesh. T4 thinks that the rural English teachers are overloaded. They even need to conduct classes for other subjects due to insufficiency of teachers. To T4, the mentioned cause is one of the major obstacles to implementing CLT in rural secondary schools. Teachers are most often bored with and tired of teaching students. T6, another rural CLT practitioner, also gives the same statement. T6 gives similar opinion and states that poor socio-economic condition is no less responsible for not implementing CLT in rural areas of Bangladesh. A large number of students are from poor background. They cannot even attend classes regularly. Similarly T4 too supports the statement.

The weak academic background which is pointed out by T5 is another hindrance to implementing CLT in rural areas of Bangladesh. According to $\mathrm{T} 5$ and $\mathrm{T} 7$, the students getting admitted to secondary schools have poor knowledge of English. It often becomes difficult for English teachers to conduct CLT oriented classes. T7 opines that these students are neither motivated by family nor by schools to learn English through CLT. Guardians are either reluctant to know or ignorant about what happens at students' English classes.

That Anglo-phobia hampers the CLT implementation in rural areas is the view of T6. Due to the unavailability of the skilled English teachers of the primary level and the deep influence of their L1 upon the learners, implementation of CLT is hampered in rural Bangladesh (T2 \& T6).

T2 also points out that the lack of confidence in learners causes their moral weakness in learning and using English at the secondary level. T7 believes that introvert attitude of the rural students is a great hindrance to implementing CLT at the rural secondary level schools. Many students, from very early age either due to shyness or lack of confidence, are reluctant to interact with teachers. Most of the students often do not actively participate in class activities like group works, pair works, debate, etc. They are even afraid of asking their English teachers any questions. T1, who has been teaching for a long time at the secondary level, also supports T7. T1 points out a very burning issue. T1 thinks the corrupt 
administration is also greatly liable for the failure of CLT to function perfectly at the rural areas of Bangladesh. Sometimes they appoint unskilled teachers through corruption at the rural areas. These unskilled teachers cannot handle the standard method of teaching English.

The training for CLT practitioners at the rural areas is not available. Sometimes a small portion of teachers are given opportunities to participate in CLT training. T8 opines that wrong selection of teachers by authority is an impediment to implementing the method at the rural schools. Sometimes suitable teachers are not chosen for training; rather less skilled teachers get opportunity. It often strikes and demoralizes other English teachers. T3 has the same opinion. He also opines that the lack of follow-up training is also greatly responsible for CLT not being implemented properly at the rural secondary level schools.

\section{Recommendations}

The following recommendations are made based on the problems that were indentified in this paper:

- English language teachers should be trained in CLT. They need to be made aware of the CLT principles and the ways in which these principles are practiced within language classrooms.

- The official textbook (English for Today for classes 9-10) should be revised so that it is equally focused on the four skills. The rural teachers need to be continuously trained in implementing the textbook within their classrooms.

- The rural schools should be provided with adequate infrastructure and necessary resources such as audio-visual classrooms, tape recorder, cassette player, language lab, uninterrupted electricity supply, calm and quiet classrooms, etc. that are necessary for implementing CLT.

- Class size is an important issue in CLT. In rural areas in Bangladesh, class size is exceptionally large. This, however, should be checked and English language classes should not consist of more than 40 students.

- In the rural context, many English teachers still believe that the Grammar Translation Method (GTM) is better than CLT. Teachers' belief is an important factor that affects the CLT outcome. So, the teachers in the rural areas need to be trained to change their belief in teaching methodology at the secondary level schools.

- Present testing system also needs to be modified by including all the four skills in the testing system. Rural English teachers should be trained and made aware of the communicative language testing principles and procedures. 
- Follow-up training and supervision of the teachers by a strong monitoring cell can improve the current pictures of CLT in the rural areas of Bangladesh.

\section{Conclusion}

This qualitative research has focused on the problems that create hurdles to implementing CLT in rural Bangladesh. The research findings expose that the method cannot be implemented successfully due to several reasons which are:

- Unusual class size

- Lack of trained and skilled teachers

- Lack of enough tools for teaching English through CLT

- Anglo-phobia

- Lack of confidence among students

- Unwillingness of the rural students to interact within English classrooms

- Students' poor background in the English language

- Introvert nature of the students

- Ignorance and reluctance of the guardians about what learners learn within English classroom

- Teachers' excessive teaching load

- Problems with the administration in teacher appointment

Due to resource constraints and poor socio-economic condition the overall standard of the education system of Bangladesh is not up to the mark. In contrast to the city areas, the rural areas are much more lagging behind, though majority of the students are studying at rural schools. All CLT practitioners feel that the implementation of CLT in the rural areas is not satisfactory. To keep pace with the city areas, the problems of implementation of CLT in rural areas must be successfully addressed.

\section{References}

Ali, M. M., \& Walker, A. L. (2014). Bogged down ELT in Bangladesh: problems and policy. English Today, 30(2), 30-36.

Brown, H. D. (1994). Teaching by principles: an interactive approach to language pedagogy. Upper Saddle River, New Jersey: Prentice Hall Regents.

Brown, H. D. (2007). Teaching by principle; an interactive approach to language pedagogy $\left(3^{\text {rd }}\right.$ ed.). New York: Pearson Longman.

Celce-Murcia, M. (2001). Teaching English as a second or foreign language ( $3^{\text {rd }}$ ed.). Heinle: Language Learning. 


\section{IIUC STUDIES, 13}

Chowdhury, R. (2003). International TESOL training and EFL contexts: the cultural disillusionment factor. Australian Journal of Education, 47, 283-303.

Freeman, L. D. (2000). Techniques and principles in language teaching. Oxford: Oxford University Press.

Hamid, M. O., \& Baldauf, R. (2008). Will CLT bail out the bogged down ELT in Bangladesh? English Today, 24, 16-24.

Hymes, D. H. (1972). On communicative competence. In J. B. Pride, \& J. Holmes, Sociolinguistics selected readings (Ed.). Harmondsworth: Penguin.

Larsen-Freeman, D., \& Anderson, M. (2011). Techniques \& principles in language teaching. Oxford: Oxford University Press.

Larsen-Freeman, D. (2000). Techniques and principles in language teaching. Oxford: Oxford University Press.

Li, D. (1998). It's always more difficult than you plan and imagine: teachers' perceived difficulties in introducing the communicative approach in South Korea. TESOL Quarterly, 32(4), 677-703.

Nunan, D. (1988). The Learner-centred curriculum. Cambridge: Cambridge University Press

Nunan, D. (1988). Syllabus design. Oxford: Oxford University Press.

Richards, J. C., \& Schmidt, R. W. (2010). Longman dictionary of language teacbing and applied linguistics. London: Longman.

Richards, J. C., \& Rodgers, T. S. (2001). Approaches and methods in language teaching. Cambridge: Cambridge University Press.

Savignon, S. (1987). Communicative language teaching. Theory and practice, 26(4), 235-242.

Savignon, S. (1991). Communicative language teaching: state of the art. TESOL Quarterly, 25(2), 261-277.

\section{Corresponding author}

Md. Morshedul Alam can be contacted at: morshedeng82@gmail.com 